\title{
Three New Records of Hydroids (Cnidaria: Hydrozoa) in Korean Waters
}

\author{
Jung Hee Park* \\ Department of Life Science, College of Natural Sciences, The University of Suwon, \\ Gyeonggi-do 445-743
}

\begin{abstract}
Some hydroid specimens were collected from 10-14 m deep of Munseom (Jejudo Is.) on 22 June 2007, and from 20-25 m deep of Nagokkkottdongsan (Uljin) on 10 Jan. 2008 by SCUBA diving. Among the identified species, the following three species, Solanderia spinosa (Carter, 1892), Lafoea dumosa (Fleming, 1828) and Rhizocaulus verticillatus (Linnaeus, 1758) were turned out to be new to the Korean fauna.
\end{abstract}

Key words: taxonomy, hydroids, Hydrozoa, Korea

\section{INTRODUCTION}

As results of previous taxonomic studies on hydroids in Korea, 149 species/subspecies of 19 families in three orders have been known up to date. Some hydroid specimens were collected by SCUBA diving from 10-14 $\mathrm{m}$ deep of Munseom (Jejudo Is.) on 22 June 2007, and from 20-25 m deep of Nagokkkottdongsan (Uljin) on 10 Jan. 2008. Among the identified species, the following three species, Solanderia spinosa (Carter, 1892), Lafoea dumosa (Fleming, 1828) and Rhizocaulus verticillatus (Linnaeus, 1758) were turned out to be new to the Korean fauna.

The pictures of parts of colony were taken under the light microscope (Nikon Microscope ECLIPSE 80i). The whole colonies were taken with camera, Canon EOS 300D.

As a result of this taxonomic study the Korean hydroid fauna consists of 152 hydroid species/subspecies of 19 families in three orders.

\section{SYSTEMATIC ACCOUNTS}

Phylum Cnidaria

Class Hydrozoa

Order Athecatae

Family Solanderiidae

${ }^{1}$ *Solanderia spinosa (Carter, 1892) (Fig. 1A-F)

Ceratella spinosa: Spencer, 1891, p. 21.

Solanderia spinosa: Vervoort, 1962, p. 535.

\section{*To whom correspondence should be addressed \\ Tel: 82-31-220-2480, Fax: 82-31-220-2484}

E-mail: jhpark5@suwon.ac.kr
Material examind. Munseom (Jejudo Is.), 22 Jun. 2007 (S.J. Hwang).

Description. Colony rich purple-red color, about $10 \mathrm{~cm}$ long, $5 \mathrm{~cm}$ wide, composed of chitinous fibre, of which meshes more or less oblong, passing into prominent longitudinal lines on branchlets. Hydranth club shaped, with capitate tentacles and milky white. Hydrophore spatulate shaped, sporting hydranth on its base. Gonophore not examined.

Remarks. This species is similar to $S$. procumbens (see Vervoort, 1962) in the colony colar and semispatular hydrophore, but it is distinguished from the latter by oblong and longitudinal line of chitinous fibre.

Distribution. Korea, Port Natal.

Order Thecatae

Family Lafoëidae

${ }^{2}$ Lafoea dumosa (Fleming, 1828) (Fig. 2A-D)

Lafoea dumosa: Hincks, 1868, p. 200, pl. 41, figs. 1, 1a; Stechow, 1919, p. 30, fig. A1; 1923, p. 10; Totton, 1930, p. 158 , fig. 14 ; Fraser, 1944 , p. 221 , pl. 45 , fig. 205; Vervoort, 1946, p. 197, figs. 83a, 84; Yamada, 1959, p. 50; Naumov, 1969, p. 276, fig. 21, 4V, pl. 1, fig. 1; Hirihito, 1995, p. 126, fig. 36a-c, pl. 8, fig. A; Schuchert, 2000, p. 413; 2001, p. 67, figs. 54-55, p. 157, fig. 16; Galea, 2007 , p. 49 , fig. $11 \mathrm{~A}-\mathrm{E}$.

Material examined. Nagokkkottdongsan (Uljin), 10 Jan. 2008 (S.H. Kim) 20-25 m deep by SCUBA diving.

Description. Colony large and erect, straggly, almost without main trunk loosely and irregularly branched, polysiphonic component tubes parallel, each bearing hydrotheca at irregular intervals. Hydrotheca long tubular, margin without

$1 *$ 가시산호붙이히드라 (신칭), ${ }^{2}$ 가시덤불바위붙이히드라 (신칭) 

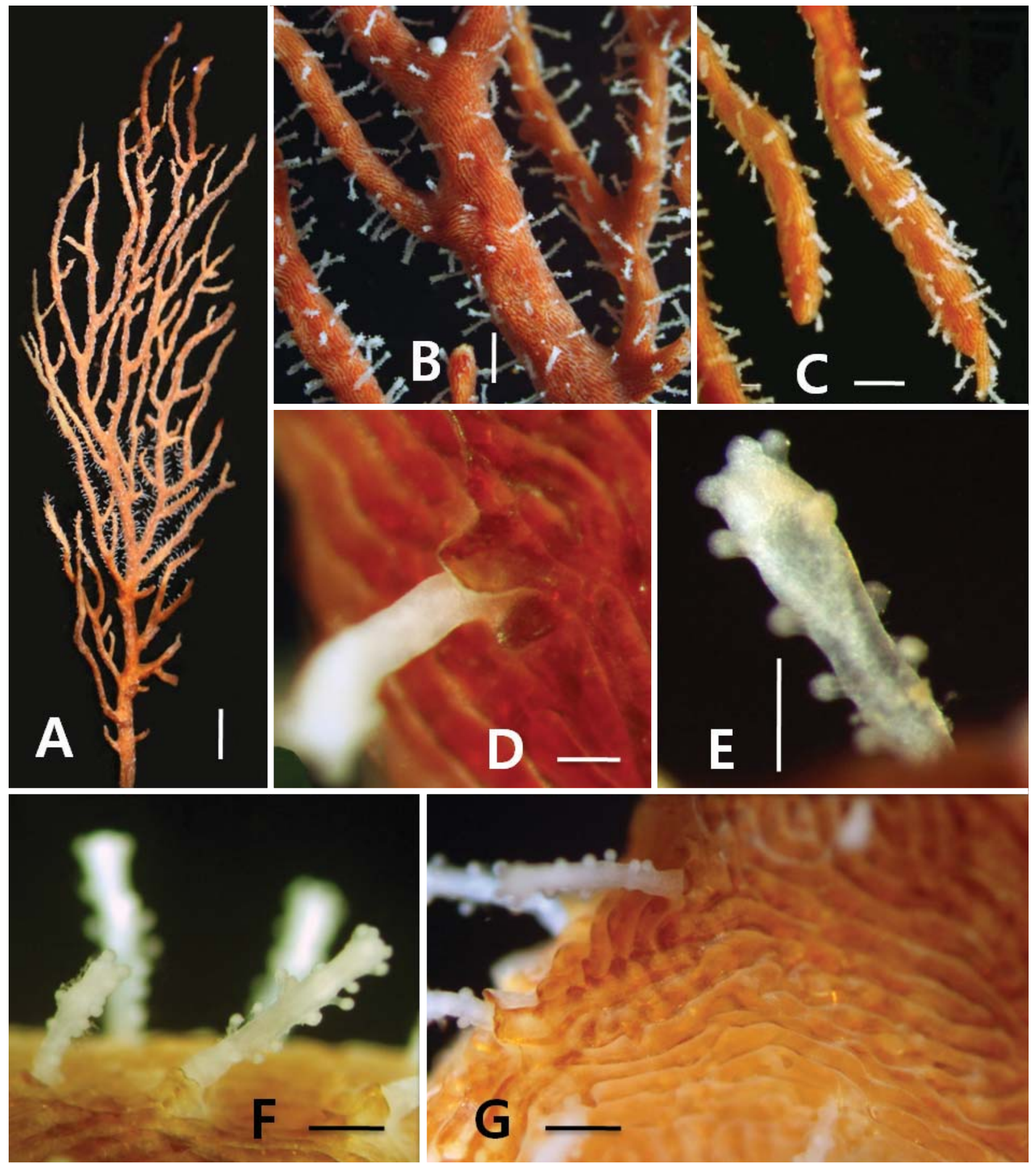

Fig. 1. Solanderia spinosa. A, colony; $B$, branching pattern; $C$, apical portions of branches; $D$, spatulated hydrophore on base of hydranth; E, F, hydranths; G, surface showing spines and grooves. Scale bars=10 mm (A), $1 \mathrm{~mm}(B, C), 100 \mu \mathrm{m}(D), 500 \mu \mathrm{m}(E)$, $300 \mu \mathrm{m}(\mathrm{F}, \mathrm{G})$.

teeth, tapering below, sometimes asymmetrically, without pedicel, so that sessile type, diaphragm and operculum lack- ing. Gonotheca rarely produced, coppinia.

Remarks. This species is similar to L. fruticosa (see Vervoort, 

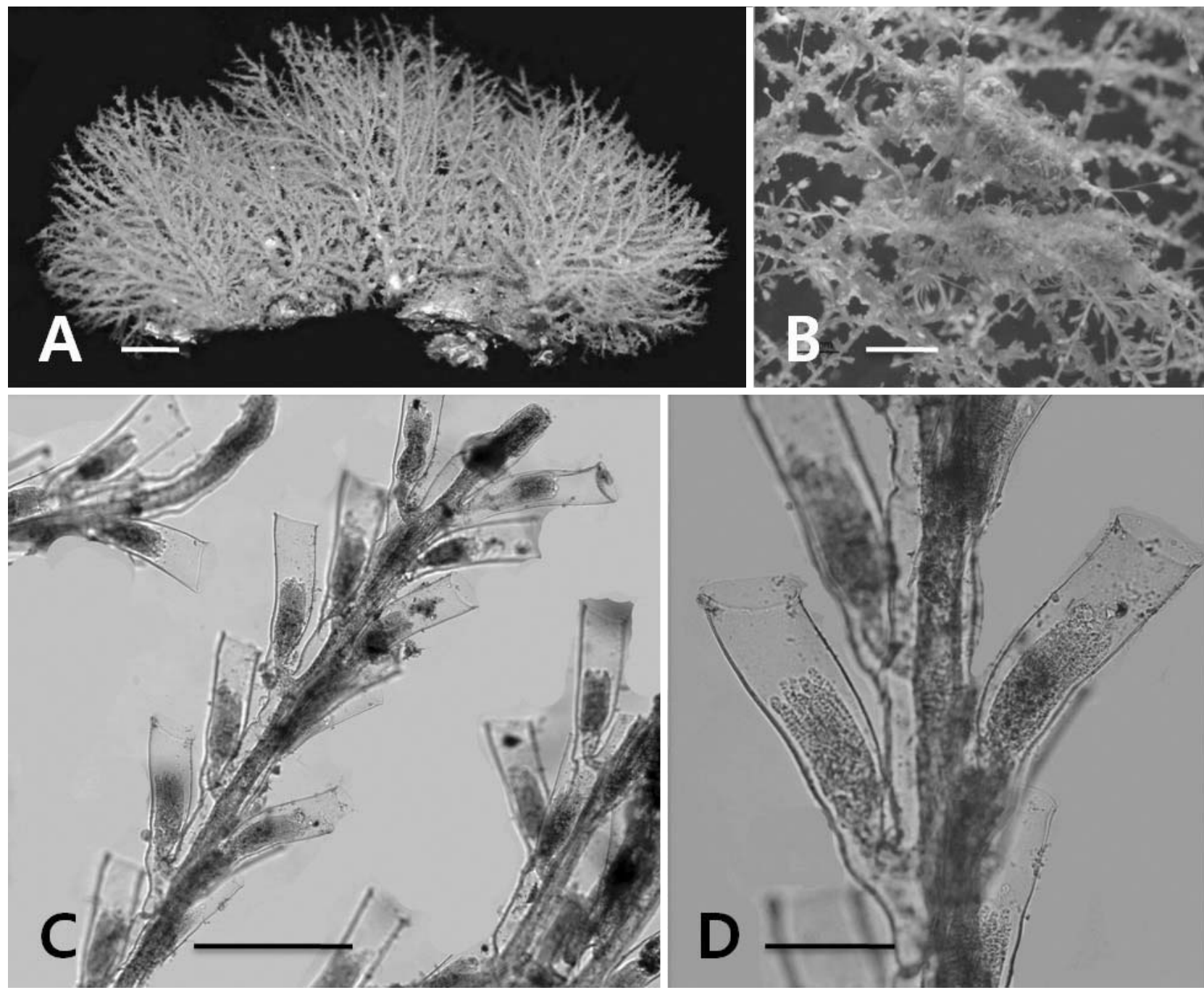

Fig. 2. Lafoea dumosa. A, whole colony; $B$, coppinia; C, parts of branches with hydrothecae; $D$, hydrothecae. Scale bars $=10 \mathrm{~mm}$ $(A), 2 \mathrm{~mm}(\mathrm{~B}), 500 \mu \mathrm{m}(\mathrm{C}), 200 \mu \mathrm{m}(\mathrm{D})$.

1945) in the shape of colony, hydrotheca and coppinia. But this species is distinguished from the latter by lacking the hydrothecal pedicel.

Distribution. Near cosmopolitan.

\section{Family Campanulariidae}

${ }^{1} *$ Rhizocaulus vertivillatus (Linnaeus, 1758) (Fig. 3A-E) Campanularia verticillata: Hincks, 1868, 167, pl. 32, figs. 1, 1a.

Rhizocaulus verticillatus: Stechow, 1919, p. 852; Cornelius, 1982 , p. 67 , fig. 7.

Verticillina verticillata: Naumov, 1969, p. 291, fig. 159.
Material examined. Nagokkkottdongsan(Uljin), 10 Jan. 2008 (S.H. Kim) 20-25 m deep by SCUBA diving.

Description. Stem erect, composed of many parallel tubes, each bearing long straight smooth hydrothecal pedicels arranged in verticils of 4-6 in number at regular intervals, unbranched but sometimes branched irregularly. Hydrotheca bell-shaped, rather large and deep, with 10-16 blunt teeth. Hydrothecal pedicel more or less annulated at top and bottom. Gonotheca bottle-shaped, with smooth, narrow and long neck and very short stalk.

Remarks. This species is similar to R. chinensis (see Rho and Park, 1979) in polisiphonic main stem and unbranched hydrothecal pedicel. But it is distinguished from the latter

$1 *$ 윤생뿌리히드라 (신칭) 

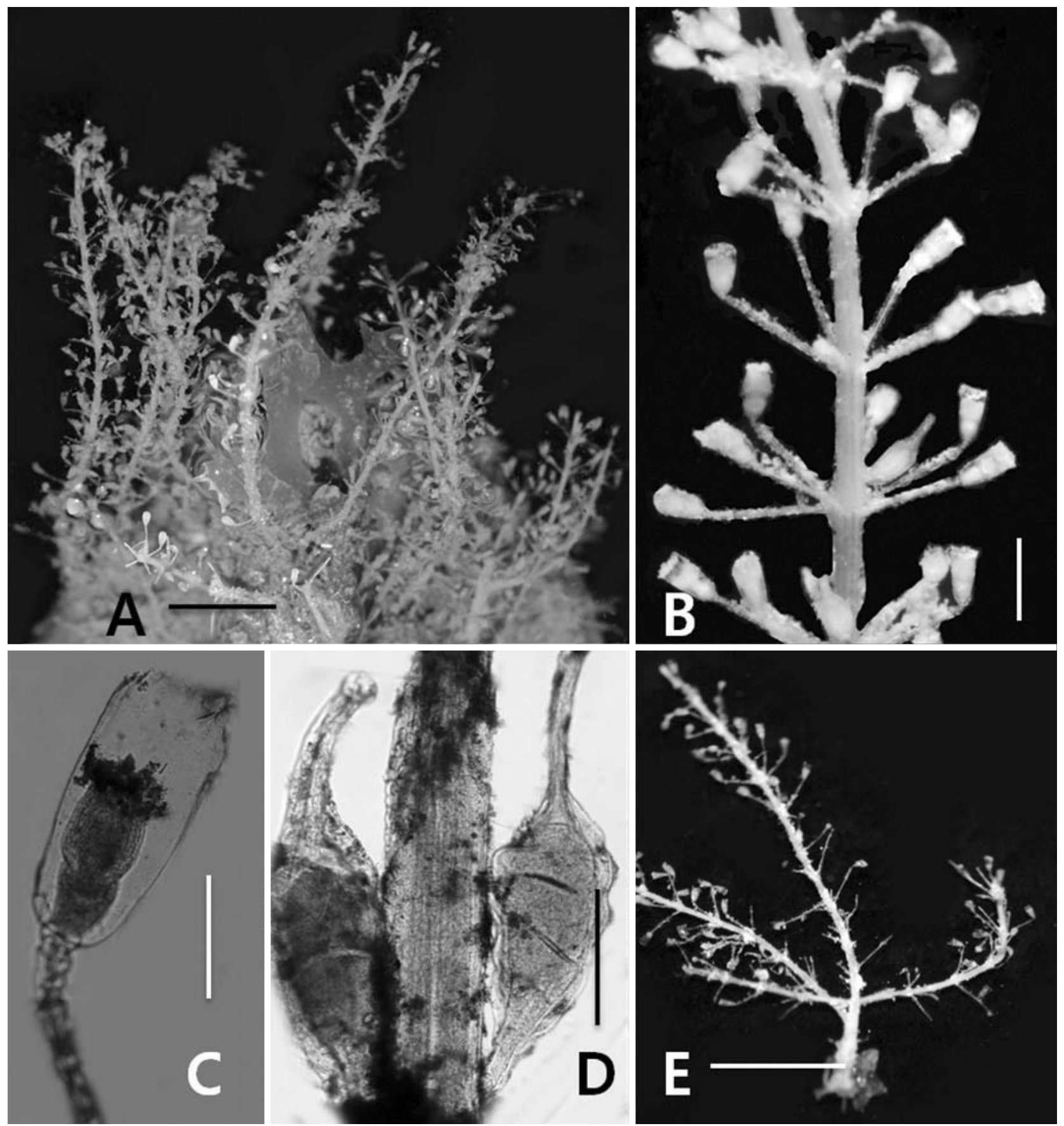

Fig. 3. Rhizocaulus verticillatus. A, colonies; $B$, verticils of hydrothecal pedicels; $C$, hydrotheca; $D$, gonothecae; $E$, branching colony. Scale bars $=10 \mathrm{~mm}(A, E), 1 \mathrm{~mm}(B), 500 \mu \mathrm{m}(C, D)$.

with semiverticillate arrangement of hydrothecal pedicels and lacking the neck of gonotheca.

Distribution. Korea, Norway, Denmark and Sweden, Barents Sea, Greenland, Roscoff (NW France), Britain, Netherlands, Belgium.

\section{ACKNOWLEDGEMENTS}

This work was supported by the Korea Research Foundation Grant funded by Korea government (MOEHRD, Basic Research Promotion Fund, KRF-2005-070-C00124). 


\section{REFERENCES}

Cornelius, P.F.S., 1982. Hydroids and medusae of the family Campanulariidae recorded from the eastern North Atlantic, with a world synopsis of genera. Bull. Br. Mus. Nat. Hist. (Zool.), 42(2): 37-148.

Fraser, C.M., 1944. Hydroids of the Atlantic coast of North America. Toronto Univ. Press, pp. 1-457, pls. 1-94.

Galea, H.R., 2007. Hydroids and hydromedusae (Cnidaria: Hydrozoa) from the Fjords region of southern Chile. Zootaxa, 1597: 1-116.

Hincks, T., 1868. A history of the British hydroid zoophytes, vol. 1.-Text, vol. II.- Plates. John van Voorst, Paternoster Row, London, pp. 1-337, figs. 1-45., pls. I- LXVII.

Hirohito, 1995. The hydroids of Sagami Bay. II. Thecata. Publs. Biol. Lab. Imp. Household, Tokyo, 1-355, pls. 1-13.

Naumov, D.V., 1969. Hydroids and hydromedusae of the USSR. Fauna S.S.S.R., 70, pp. 1-660. figs. 1-463, pls. 1-30.

Rho, B.J. and J.H. Park, 1979. A systematic study on the marine hydroids in Korea 5. Athecate hydroids. Korean J. Zool., 22: 165-174.

Schuchert, B., 2000. Hydrozoa (Cnidaria) of Iceland collected by the BIOICE Programme. Sarsia, 85: 411-438.
Schuchert, B., 2001. Hydroids of Greenland and Iceland. Bioscience, 53: 1-184.

Stechow, E., 1919. Zur Kennnis der Hydroidenfauna des Mittelmeeres, Amerikas und anderer Gebiete I. Zool. Jb. Syst., 42: 1-172.

Stechow, E., 1923. Zur Kennnis der Hydroidenfauna des Mittelmeeres, Amerikas und anderer Gebiete II. Zool. Jb. Syst., 47: 29-270.

Spenser, W.B., 1891. On the structure of Ceratella fusca (Gray). Trans. Roy. Soc. Vict., 2(2): 8-24, pls. 2, 3, 3a.

Tootton, A. K., 1930. Coelenterata. Part V. Hydroida. Zool., 5(5): 131-252.

Vervoort, W., 1946. Fauna van Nederland Hydrozoa (C 1) A. Hydropolypen. Rijksmus. Nat. Hist., Leiden, pp. 1-336.

Vervoort, W., 1962. A redescription of Solanderia gracilis Duchassaing \& Michelin, 1846, and general notes on the family Solanderiidae (Coelenterata: Hydorzoa). Bull. Mar. Sci. Gulf Caribb., 12(3): 508-542.

Yamada, M., 1959. Hydroid fauna of Japanese and its adjacent waters. Akkeshi Mar. Biol. Stat., 9: 1-101.

Received January 21, 2009 Accepted March 11, 2009 